\title{
Article \\ Simulation Accuracy of EROSION-3D Model for Estimation of Runoff and Sediment Yield from Micro-Watersheds
}

\author{
Manmohanjit Singh ${ }^{1}$, Abrar Yousuf ${ }^{1, *}$, Harpreet Singh ${ }^{1}$, Sukhdeep Singh ${ }^{1}$, Kerstin Hartsch ${ }^{2}$, \\ Michael von Werner ${ }^{2}$, Abdulrazak H. Almaliki ${ }^{3} \mathbb{\infty}$, Ashraf Y. Elnaggar ${ }^{4} \mathbb{O}$, Enas E. Hussein ${ }^{5, *(1)}$ and Hager R. Ali ${ }^{6}$ \\ 1 Regional Research Station, Punjab Agricultural University, Ballowal Saunkhri, S.B.S. Nagar, \\ Balachaur 144521, India; mmjsingh@pau.edu (M.S.); harpreet2379@gmail.com (H.S.); \\ sukhdeepdosanjh6@gmail.com (S.S.) \\ 2 IPROconsult GmbH Schnorrstraße 70, 01069 Dresden, Germany; kerstin.Hartsch@iproconsult.com (K.H.); \\ michael.von.werner@geognostics.de (M.v.W.) \\ 3 Civil Engineering Department, College of Engineering, Taif University, Taif 21944, Saudi Arabia; \\ a.almaliki@tu.edu.sa \\ 4 Department of Food Nutrition Science (Previously Chemistry), College of Science, Taif University, \\ Taif 21944, Saudi Arabia; aynaggar@Tu.edu.sa \\ 5 National Water Research Center, Shubra El-Kheima 13411, Egypt \\ 6 Egyptian Petroleum Research Institute, Cairo 11727, Egypt; Hagerchem@gmail.com \\ * Correspondence: er.aywani@pau.edu (A.Y.); enas_el-sayed@nwrc.gov.eg (E.E.H.)
}

Citation: Singh, M.; Yousuf, A.; Singh, H.; Singh, S.; Hartsch, K.; von Werner, M.; Almaliki, A.H.;

Elnaggar, A.Y.; Hussein, E.E.; Ali, H.R. Simulation Accuracy of EROSION-3D Model for Estimation of Runoff and Sediment Yield from Micro-Watersheds. Water 2022, 14, 280. https://doi.org/10.3390/ w14030280

Academic Editor: Renato Morbidelli

Received: 13 December 2021

Accepted: 16 January 2022

Published: 18 January 2022

Publisher's Note: MDPI stays neutral with regard to jurisdictional claims in published maps and institutional affiliations.

Copyright: (c) 2022 by the authors Licensee MDPI, Basel, Switzerland. This article is an open access article distributed under the terms and conditions of the Creative Commons Attribution (CC BY) license (https:// creativecommons.org/licenses/by/ $4.0 /)$.

\begin{abstract}
The present study was conducted to test the efficiency and applicability of the EROSION-3D (Jürgen Schmidt, Berlin, Germany) model in the lower Shivaliks of Northwest India. Two similar microwatersheds in terms of soil characteristics and land use were selected for calibration and validation of the model. The model was calibrated using the data from seven rainstorms of micro-watershed A and validated using data from 11 rainstorms in micro-watershed B. After calibration, the overall statistical parameters, namely RMSE (0.44 mm), percent error (4.92), correlation coefficient (0.94) and model efficiency $(88 \%)$, clearly indicate that the model simulated runoff quite well in conditions prevalent in Shivaliks. For sediment yield, the overall statistical parameters, namely RMSE $\left(0.365 \mathrm{Mg} \mathrm{ha}^{-1}\right)$, percent error (12.71), correlation coefficient (0.97) and model efficiency (88.32\%), clearly indicate that the model simulated sediment yield also quite well. During the validation process, for runoff, RMSE $(1.72 \mathrm{~mm})$, percent error (19.19), correlation coefficient (0.94), and model efficiency $(81.25 \%)$ and, for sediment yield, RMSE $\left(0.19 \mathrm{Mg} \mathrm{ha}^{-1}\right)$, percent error (17.16), correlation coefficient (0.97), and model efficiency $(74.48 \%)$ clearly demonstrate the reasonable accuracy of the EROSION-3D model to predict runoff and soil loss from micro-watersheds located in Shivaliks of Northwest India. Therefore, the EROSION-3D may be used as decision support system for soil conservation management decisions in the lower Shivaliks of India.
\end{abstract}

Keywords: EROSION-3D; runoff; sediment yield; Shivaliks; watersheds

\section{Introduction}

Land degradation is the decline in the productivity potential of the soil [1]. Land degradation results in soil compaction, salinization, acidification and soil loss from wind and water erosion [2]. The land degradation should be perceived in the context of policy, socio-economic conditions and the environment, as it has implications on many policy issues, including climate change, food production and security, flood and drought management, etc. [3,4]. Land degradation has long been recognized as having a negative influence on agricultural and food production. Soil erosion is identified as the chief cause of land degradation [5]. Soil erosion results in decreased soil quality thereby decreasing the crop yields [6]. Soil erosion also results in the formation of rills and gullies which render the arable lands unfit for the cultivation. Soil erosion generates huge quantity of sediments which result in siltation of downstream water reservoirs including lakes and 
dams [7]. The siltation of water reservoirs results in reduction in the storage capacity which affects the supply of water for different water demands [8]. More than half of all fertile, food-producing soils globally are now classified as degraded [9]. It has been estimated that about 1964.4 million hectares (M ha) of the global soils are affected by anthropogenic degradation out of which, $1903 \mathrm{M}$ ha is affected by water erosion [10,11]. In India, about 36.7\% (120.7 M ha) of the total land suffers from various forms of degradation with water erosion being its chief contributor (68.4\%) [12]. The gross erosion is estimated as 5.11 Gigatons per year (1559 $\mathrm{Mg} \mathrm{km}^{-2}$ year $^{-1}$ ) out of which 34.1\%, 22.9\% and 43.0\% are discharged in reservoirs, oceans and rivers, respectively [13]. About 74 million tons of nutrients are lost annually due to erosion resulting in the monetary loss of about one billion dollars $[10,14]$. Although soil erosion can be observed in all major types of ecosystems, in India, its most disastrous effects are being witnessed by the fragile ecosystems such as the Shivalik foothills. The Shivalik foothills are the lowermost part of the Himalayan Mountain chain covering an area of 2.14 M ha in five states of India. In Punjab, Shivalik foothills cover an area of about $0.39 \mathrm{M}$ ha which is locally known as the Kandi area. The Shivalik foothills are considered as the most fragile and vulnerable ecosystem in the Himalayan region and are facing the most dangerous effects of climate change [15]. These foothills are formed of erodible and weakly cemented sandstones with inter-bedded clay and silt strata. During the monsoon season, heavy rainstorms cause significant erosion and peak flash flows [16]. This region is characterized by erratic behavior of rainfall, undulating topography, steep slopes and lack of vegetation which results in high soil erosion $[17,18]$. The average annual soil loss in the Shivalik foothills is $16 \mathrm{Mg} \mathrm{ha}^{-1} \mathrm{year}^{-1}$ and, in some watersheds, it is more than $80 \mathrm{Mg} \mathrm{ha}^{-1}$ year $^{-1}$ [19]. Sheet and rill erosion is the most common type of erosion prevalent in the agricultural fields while gully erosion is predominantly found at higher elevations [15]. The agriculture in this region is mostly rainfed, as the crop security depends entirely on the monsoon rainfall.

Therefore, there is need to understand the process of runoff and soil erosion so as to estimate its extent in the Shivalik region for planning and implementation of the conservation strategies to stop the ecological degradation. The data of runoff and soil erosion are pre-requisite to plan and implement the various activities of watershed management. Moreover, in rainfed areas, as prevailing in the Shivalik regions, the prediction and assessment of runoff and soil erosion from a watershed are important for evaluation of watershed management practices and development of water resources. However, manual monitoring of hydrological data in all the watersheds is difficult due to complexities in data requirement, inaccessibility of the watersheds, high expenditure and extensive requirement of trained personnel and automated apparatuses [18]. The hydrological data monitoring stations are in decline due to number of constraints including monetary constraints and lack of technical staff $[20,21]$.

Runoff and soil erosion are highly complex phenomena as the processes are affected by many factors, including climate, soil type, topography and land use which makes its simulation extremely difficult [22]. The application of data-driven modelling methods to deliver improved runoff and sediment yield estimates has received considerable attention in recent years $[23,24]$. Hydrological models have been used to study and understand the complex runoff and soil erosion processes. The application of hydrological models has made it easier to estimate the runoff and soil erosion from the watersheds. Among the various types of available hydrological models, the distributed watershed models are very helpful in understanding the process behind runoff and soil erosion. These models have proved to be very useful for simulation of various processes related to the management of water, including water quality, sediment yield, groundwater flow etc., however, for their proper implementation, calibration and validation of these models is extremely important [25]. These models have been used worldwide for simulating runoff and soil erosion processes and some of the models have also been tested in the Shivaliks of India [26]. Most of the hydrological models are site-specific in nature and, hence, their efficiency and applicability need to be tested before using them as the decision support systems for 
simulation of best management practices. EROSION-3D is a physically-based distributed hydrological model which simulates runoff and soil erosion from the watersheds. As the EROSION-3D model is a raster-based model, it requires a grid-cell presentation of the watershed. EROSION-3D needs fewer input soil parameters as compared with other hydrological models such as Watershed Erosion Prediction Project (WEPP), European Soil Erosion Model (EUROSEM), etc. There are many advantages while using EROSION-3D. For instance, the modeling approach has unlimited transferability to other situations, single event modeling is permitted, simulations generated by the model contain a high spatial and temporal resolution, sediment particle transport and sedimentation can be simulated for sediment budget estimation, and a detailed parameter database is available for the input used by the model based on extended field results for various types of soils and land uses. Moreover, a limited number of parameters are used in this model and it is compatible with the GIS software [27]. This model has been tested at various locations [28-31] and predictions were reliable but it has not been tested in the conditions prevailing in the lower Shivaliks of India. Keeping this in view, the present study was undertaken to determine the simulation accuracy and applicability of the EROSION-3D model to estimate runoff and sediment yield from micro-watersheds in Shivaliks of Northwest India.

\section{Materials and Methods}

\subsection{Study Areas}

In this study, two micro-watersheds named as micro-watershed A (located at Regional Research Station, Ballowal Saunkhri) and micro-watershed B (located at Harwan village, Garhshankar, Hoshiarpur) were selected in the lower Shivaliks of Punjab, India (Figure 1). The average annual rainfall observed at micro-watershed A and micro-watershed B was $1051 \mathrm{~mm}$ and $1081 \mathrm{~mm}$, respectively. However, more than $85 \%$ of the rainfall is observed in three months from July to September during the monsoon period [32]. The characteristics of the micro-watersheds are given in Table 1.

\subsection{Hydrological Data}

\subsubsection{Rainfall}

Rainfall data during the study period (2017 and 2018) were measured using the recording type rain gauges installed at both micro-watersheds. The rainfall intensity was calculated for each $7 \mathrm{~min}$ of the rainstorms from the cumulative rainfall vs. time graph.

\subsubsection{Runoff}

The study watersheds were gauged for measurement of surface runoff. An $\mathrm{H}$ flume and rectangular weir were installed at the outlet of micro-watershed $\mathrm{A}$ and micro-watershed $B$, respectively. The automatic water level recorders were installed over the gauging stations which continuously measured the head of water flowing over the structures. The head of water was then converted into the daily discharge $\left(\mathrm{m}^{3} \mathrm{~s}^{-1}\right)$ which was further converted into runoff depth $(\mathrm{mm})$ using the watershed area and runoff duration.

\subsubsection{Sediment Yield}

Sediment yield was measured by taking periodic runoff samples in sediment sampling bottles of one liter capacity during rainstorms. Usually, 4-5 runoff samples were collected during an event depending on the duration of the storm. The runoff samples were collected in such a way that these samples represented the rising limb, the peak segment and the recession limb of the hydrograph. The collected runoff samples were oven- dried at $105^{\circ} \mathrm{C}$ for $24 \mathrm{~h}$ and the dry weight of sediments was noted down. The amount of sediments collected in a sample was multiplied with the volume of runoff from that storm to calculate the total soil loss during a rainfall event. 


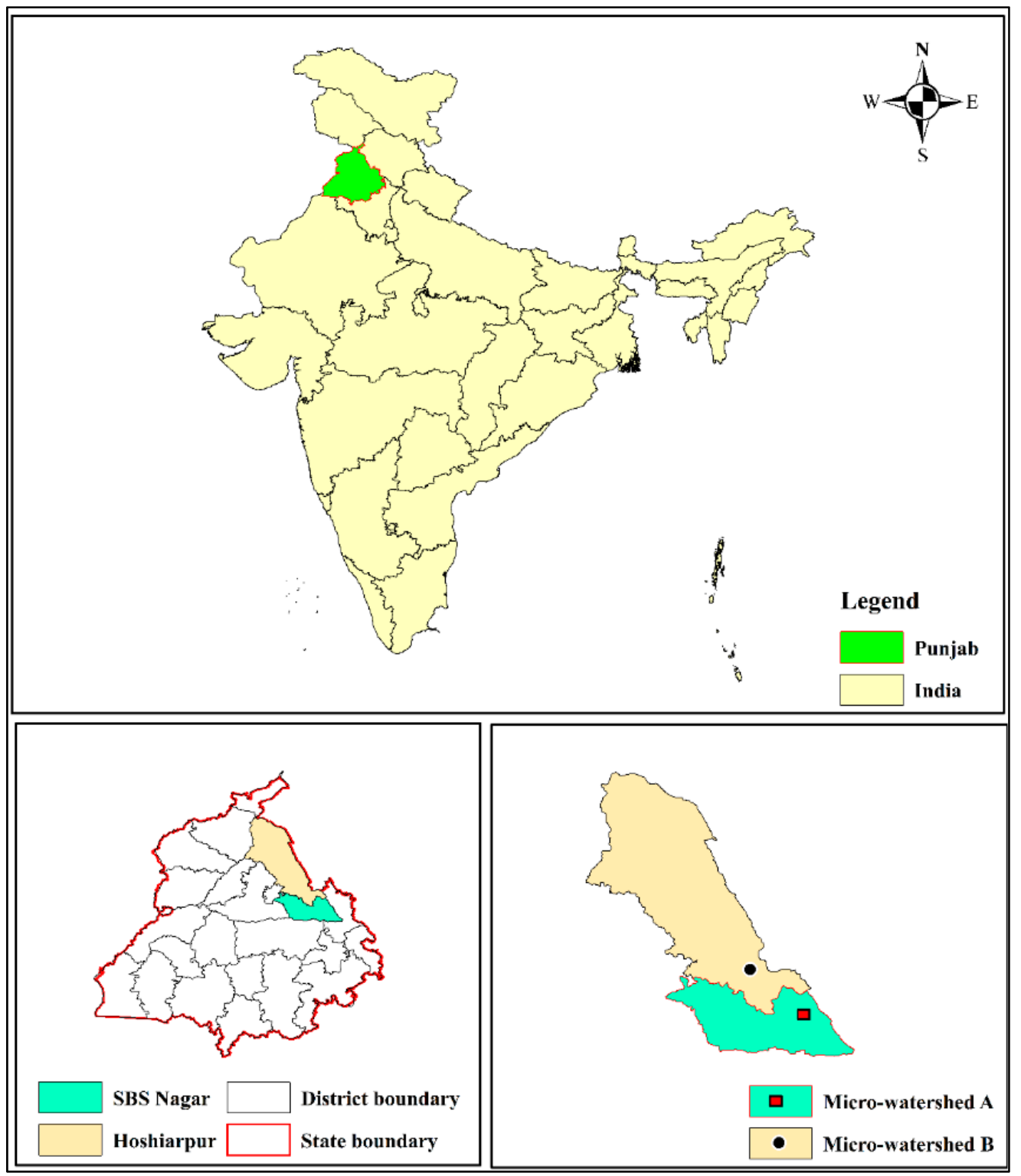

Figure 1. Location map of micro-watersheds A and B.

Table 1. Basic characteristics of selected micro-watersheds.

\begin{tabular}{cccc}
\hline Sr. No. & Description & Micro-Watershed A & Micro-Watershed B \\
\hline 1. & Latitude & $30.40^{\circ}$ to $32.30^{\circ} \mathrm{N}$ & $31.36^{\circ}$ to $31.38^{\circ} \mathrm{N}$ \\
2. & Longitude & $75.30^{\circ}$ to $75.48^{\circ} \mathrm{E}$ & $76.48^{\circ}$ to $76.49^{\circ} \mathrm{E}$ \\
3. & Elevation (m) & 355 & 497 \\
4. & Slope $\%$ & 6.98 & 1.75 \\
5. & Catchment area (ha) & 1.86 & 1.52 \\
\hline
\end{tabular}

\subsection{Erosion-3D Model}

The EROSION-3D model is a physically-based hydrological model mainly developed for simulating runoff and soil erosion processes on arable lands. The EROSION-3D is a raster-based model and hence represents the watershed in the form of grids/cells. The model mainly consists of two sub-models, viz. infiltration and erosion sub-models. The erosion sub-model represents erosion process in the form of detachment, transport and deposition of soil particles. The erosion sub-model calculates erosion using the momentum flux approach. The infiltration sub-model determines the infiltration rate based on modified 
the Green and Ampt equation [33]. The readers are referred to [27,34,35] to get the detailed information about model processes.

\subsection{Preparation of Model Input Files}

\subsubsection{Climate File}

The rainfall data for each rainstorm during the study period were recorded using the self-recording rain gauges installed near both the study watersheds. The rainfall intensity of each rainstorm was calculated for every 7-min interval. Rainfall charts from recording type rain gauges were analyzed in order to calculate the rainfall intensity.

\subsubsection{Soil File}

Soil sampling was carried out from 0-15 cm and 15-30 cm depths using standard procedures [36]. The air-dried samples were ground and passed through a 2-mm sieve for analysis of various physical and chemical characteristics, viz. soil texture, bulk density, initial moisture and organic carbon. The data obtained after the analysis were used to prepare the soil input file for the model.

Various other parameters required by the model, such as skin factor, resistance to erosion and surface roughness were taken from a study conducted in October 2017 at Regional Research Station, Ballowal Saunkhri [37]. The skin factor, resistance to erosion and surface roughness are calculated using the following formulae [37]:

$$
\begin{gathered}
\mathrm{S}_{\mathrm{f}}=-10.1057+0.0048 \times \text { Bulk }+3.2865 \times \text { Corg }+0.1487 \times \text { Moist } \\
-0.2657 \times \mathrm{Cl}-0.0291 \times \mathrm{Si} \\
\mathrm{E}=-0.0074+5.2 \times 10^{-6} \times \text { Bulk }+0.00632 \times \mathrm{Corg}-0.063 \times \text { Rough } \\
-3.52 \times 10^{-4} \times \mathrm{Cl}-8.2 \times 10^{-5} \times \mathrm{Si} \\
\mathrm{n}=\mathrm{V}_{\mathrm{q}}^{-5 / 3} \times \mathrm{q}_{0}^{2 / 3} \times \mathrm{S}^{1 / 2}
\end{gathered}
$$

where, $S_{\mathrm{f}}$ is skin factor (-), $\mathrm{E}$ is resistance to erosion $\left(\mathrm{N} \mathrm{m}^{-2}\right), \mathrm{n}$ is surface roughness $\left(\mathrm{s} \mathrm{m}^{-1 / 3}\right)$, Bulk is bulk density $\left(\mathrm{kg} \mathrm{m}^{-3}\right), \mathrm{C}_{\text {org }}$ is organic carbon (\%), Moist is soil moisture (\%), Rough is surface roughness $\left(\mathrm{s} \mathrm{m}^{-1 / 3}\right), \mathrm{Cl}$ is clay content $(\%), \mathrm{Si}$ is silt content $(\%), \mathrm{S}$ is slope inclination $\left(\mathrm{m} \mathrm{m}^{-1}\right), \mathrm{q}_{\mathrm{o}}$ is mean runoff flow rate from overflow phase $\mathrm{m}^{3}\left(\mathrm{~s}^{-1} \mathrm{~m}^{-1}\right)$ and $\mathrm{V}_{\mathrm{q}}$ is runoff velocity $\left(\mathrm{m} \mathrm{s}^{-1}\right)$.

\subsubsection{Relief/Slope}

The total station survey was carried out for both the watersheds to prepare the digital elevation models of $1 \times 1 \mathrm{~m}$ resolution. The average elevation of the micro-watershed A was 355 above the mean sea level, whereas it was $497 \mathrm{~m}$ for micro-watershed B (Figure 2A,B).

\subsubsection{Land Use}

The land use was evaluated by surveying the study micro-watersheds during the monsoon season and the information was recorded field-wise. The information was digitized as a layer in GIS. The micro-watershed A was inhabited by maize, moong, mash and perennial grasses, whereas micro-watershed B was dominantly occupied by maize only (Figure 3A,B). 

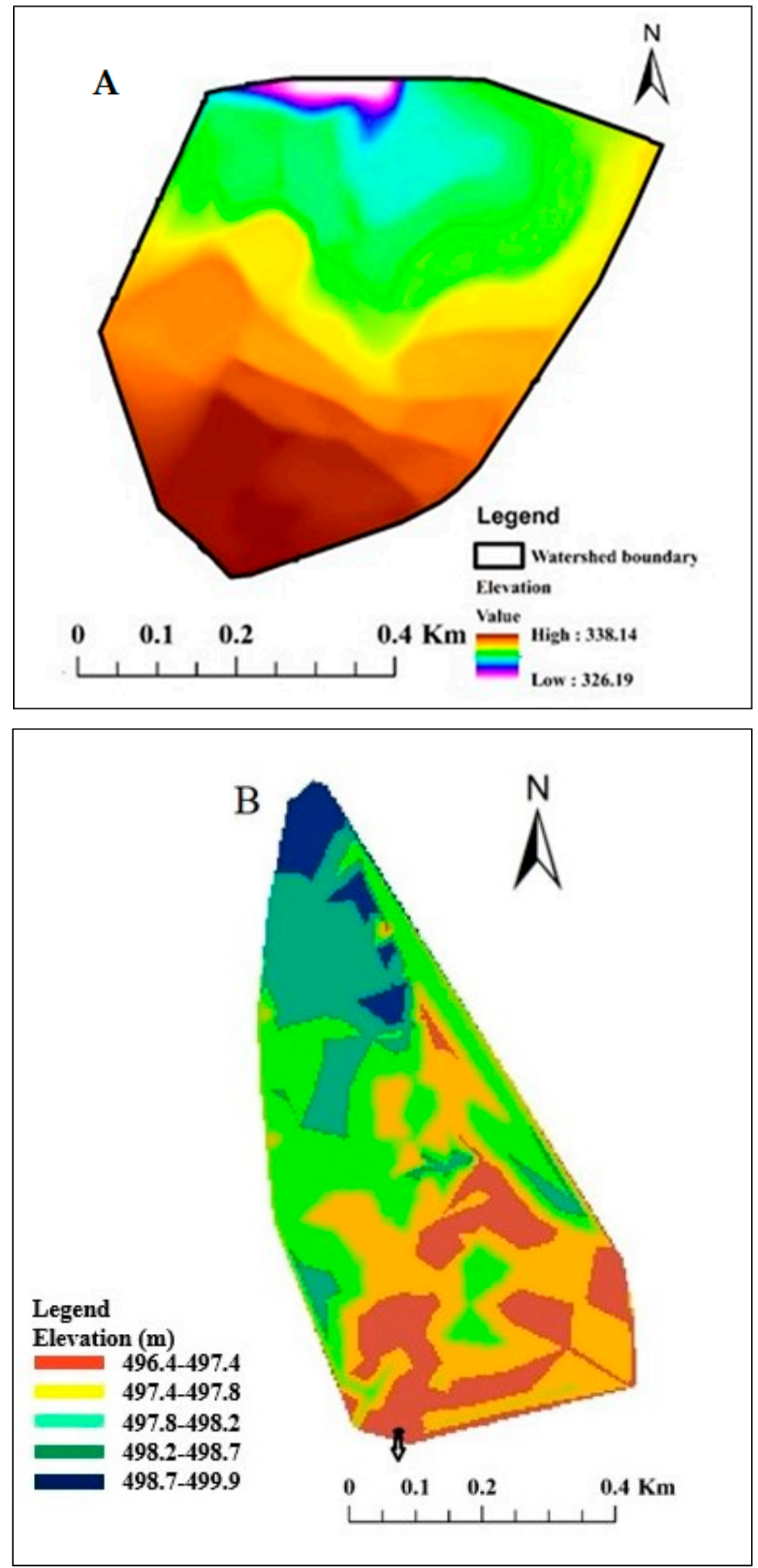

Figure 2. (A) Digital elevation model of micro-watershed A. (B) Digital elevation model of microwatershed B. 

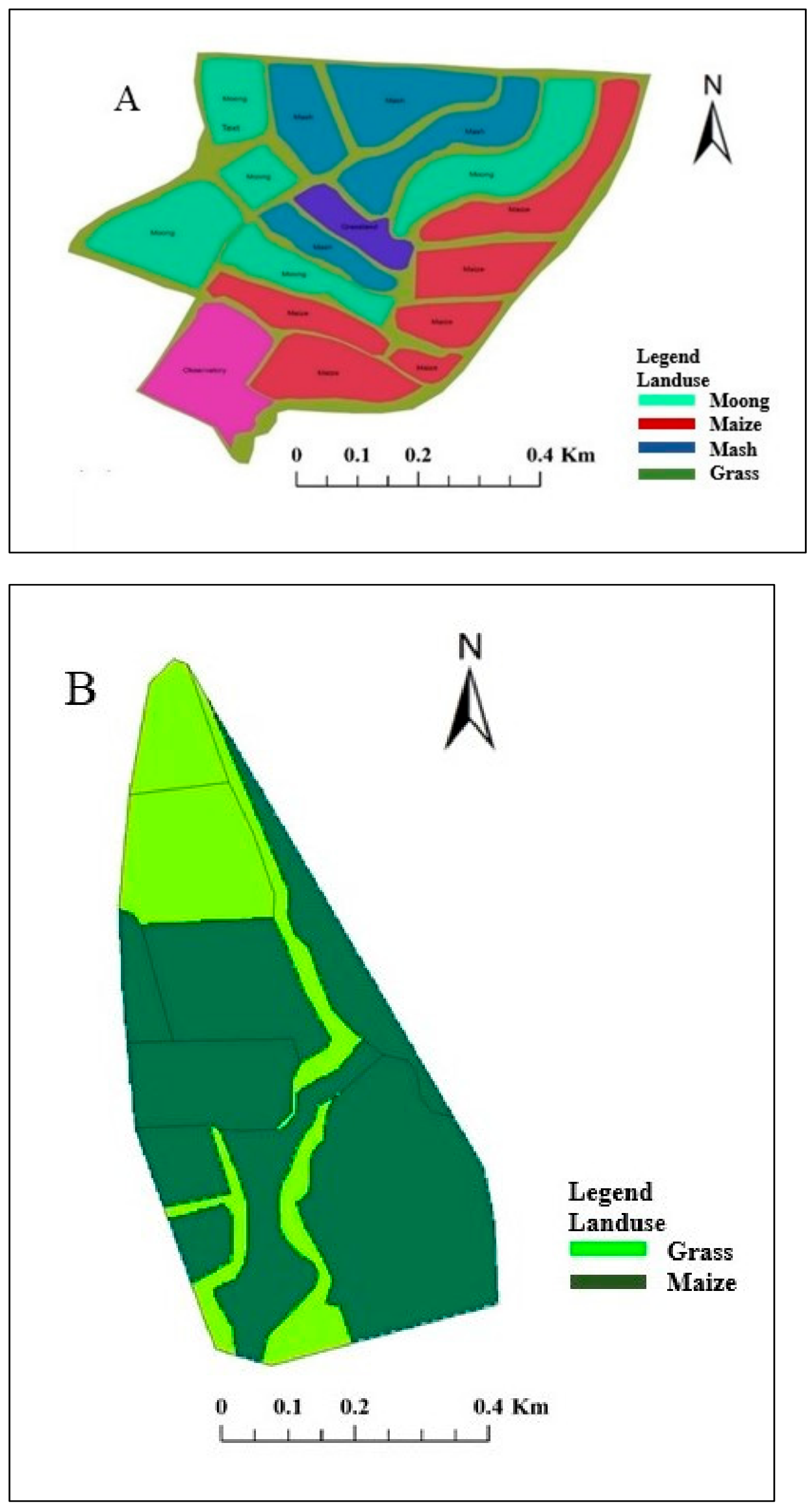

Figure 3. (A) Land use map of micro-watershed A. (B) Land use of micro-watershed B. 


\subsection{Calibration and Validation of EROSION-3D Model}

Calibration is the important step to increase the reliability of the model in that particular soil, climate, land use management practices in that watershed. The manual calibration based on a trial-and-error procedure was used in the study [38]. The model was calibrated for seven rainstorm events observed at micro-watershed A. Skin factor, resistance to erosion and surface roughness were used to calibrate the model against observed runoff and soil loss. Several simulations were performed adjusting the parameter values until the deviation between observed and simulated data was minimum. The model was validated with runoff and sediment yield data available from eleven rainstorms recorded at micro-watershed B. The model performance was statistically analyzed by calculating the percent error, root mean square error (RMSE), correlation coefficient (r) and Nash-Sutcliffe model efficiency [39].

\section{Results}

\subsection{Rainfall Characteristics}

During the monsoon season of 2018, 33 and 34 rainy days were observed at microwatershed $\mathrm{A}$ and micro-watershed $\mathrm{B}$, respectively. Out of these rainy days, only seven and eleven rainfall events resulted in runoff at micro-watershed $\mathrm{A}$ and micro-watershed $\mathrm{B}$, respectively. The $\mathrm{I}_{30}$ (30 min maximum rainfall intensity) varied from 101.1 to $197.7 \mathrm{~mm} \mathrm{hr}^{-1}$, whereas the kinetic energy of the rainfall events varied from 1.06 to $18.19 \mathrm{MJ} \mathrm{ha}^{-1}$ at micro-watershed A (Table 2). The $\mathrm{I}_{30}$ was in the range of 59.4 to $496.2 \mathrm{~mm} \mathrm{hr}^{-1}$, whereas the kinetic energy of the rainfall events was found in the range of 7.16 to $82.40 \mathrm{MJ} \mathrm{ha}^{-1}$ at micro-watershed B (Table 3).

Table 2. Rainfall characteristics at micro-watershed A.

\begin{tabular}{|c|c|c|c|c|c|c|}
\hline $\begin{array}{c}\text { Event } \\
\text { No. }\end{array}$ & $\begin{array}{l}\text { Rainfall } \\
(\mathrm{mm})\end{array}$ & $\begin{array}{c}\text { Rainfall } \\
\text { Duration (min) }\end{array}$ & $\begin{array}{c}\mathrm{I}_{7.5} \\
\left(\mathrm{~mm} \mathrm{hr^{-1 }}\right)\end{array}$ & 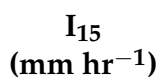 & $\begin{array}{c}\mathrm{I}_{30} \\
\left(\mathrm{~mm} \mathrm{hr^{-1 }}\right)\end{array}$ & $\begin{array}{l}\text { Total KE } \\
\left(\mathrm{MJ} \mathrm{ha}^{-1}\right)\end{array}$ \\
\hline 1 & 55.2 & 210 & 28.2 & 51.9 & 101.1 & 8.46 \\
\hline 2 & 71.8 & 84 & 91.8 & 149.7 & 197.7 & 13.99 \\
\hline 3 & 34 & 42 & 53.9 & 91.6 & 186.9 & 3.46 \\
\hline 4 & 34.8 & 63 & 79.8 & 126.6 & 190.8 & 1.06 \\
\hline 5 & 63.1 & 112 & 67.3 & 98.4 & 139.3 & 5.03 \\
\hline 6 & 76.2 & 210 & 40.2 & 80.4 & 146.4 & 7.49 \\
\hline 7 & 139.6 & 194 & 57.9 & 86.1 & 120.3 & 18.19 \\
\hline
\end{tabular}

Table 3. Rainfall characteristics at micro-watershed B.

\begin{tabular}{|c|c|c|c|c|c|c|}
\hline $\begin{array}{l}\text { Event } \\
\text { No. }\end{array}$ & $\begin{array}{c}\text { Rainfall } \\
(\mathrm{mm})\end{array}$ & $\begin{array}{c}\text { Rainfall } \\
\text { Duration (min) }\end{array}$ & $\begin{array}{c}\mathrm{I}_{7.5}(\mathrm{~mm} \\
\left.\mathrm{hr}^{-1}\right)\end{array}$ & $\begin{array}{c}\mathrm{I}_{15}(\mathrm{~mm} \\
\left.\mathrm{hr}^{-1}\right)\end{array}$ & $\begin{array}{c}\mathrm{I}_{30}(\mathrm{~mm} \\
\left.\mathrm{hr}^{-1}\right)\end{array}$ & $\begin{array}{c}\text { Total KE } \\
\left(\text { MJ ha }^{-1}\right)\end{array}$ \\
\hline 1 & 35.2 & 147 & 42.0 & 54.4 & 92.8 & 7.77 \\
\hline 2 & 38.5 & 118 & 79.2 & 141.3 & 232.8 & 14.43 \\
\hline 3 & 51.2 & 172 & 166.2 & 298.2 & 496.2 & 35.20 \\
\hline 4 & 24.2 & 70 & 36.0 & 73.5 & 127.5 & 7.16 \\
\hline 5 & 16.2 & 28 & 59.4 & 59.4 & 59.4 & 9.11 \\
\hline 6 & 47.2 & 116 & 52.8 & 91.2 & 112.8 & 10.71 \\
\hline 7 & 12.2 & 42 & 24.0 & 46.5 & 67.5 & 82.40 \\
\hline 8 & 57.7 & 160 & 48.0 & 92.4 & 92.4 & 12.47 \\
\hline 9 & 85.3 & 103 & 33.8 & 76.1 & 129.3 & 14.42 \\
\hline 10 & 82.0 & 178 & 40.2 & 74.5 & 117.0 & 17.70 \\
\hline 11 & 91.4 & 161 & 37.6 & 82.3 & 139.2 & 18.36 \\
\hline
\end{tabular}

\subsection{Model Calibration}

The EROSION-3D model was calibrated to simulate runoff and sediment yield using the data from seven rainstorm events at micro-watershed A during the monsoon 2018. Initially, simulations were performed without calibration to assess the model's ability to simulate runoff and sediment yield. The values of skin factor, resistance to erosion and 
surface roughness at which the best fit was obtained during the model calibration are given in Table 4 . The calibrated values of skin factor, resistance to erosion and surface roughness were found close to those obtained in the rainfall simulation experiments conducted at RRS Ballowal Saunkhri [37].

Table 4. Calibrated values of skin factor, resistance to erosion and surface roughness.

\begin{tabular}{|c|c|c|c|}
\hline Land Use & $\begin{array}{c}\text { Skin Factor } \\
(-)\end{array}$ & $\begin{array}{l}\text { Resistance to Erosion } \\
\qquad\left(\mathrm{N} \mathrm{m}^{-2}\right)\end{array}$ & $\begin{array}{l}\text { Surface Roughness } \\
\qquad\left(\mathrm{s} \mathrm{m}^{-1}\right)\end{array}$ \\
\hline Maize & 0.0057 & 0.0007 & 0.024 \\
\hline Moong and Mash & 0.138 & 0.006 & 0.075 \\
\hline
\end{tabular}

The storm-wise observed and simulated runoff and sediment yield along with the corresponding rainfall are given in Figures 4 and 5. It can be seen that the observed and simulated runoff and sediment yield are in close accordance with each other. Out of the total seven rainstorms at micro-watershed $\mathrm{A}$, the simulated runoff was higher for three rainstorms as compared to observed values, whereas for four rainstorms, the simulated runoff was lower as compared to observed values. Similarly, model overestimated the sediment yield for three storms and underestimated for four storms. The scatter diagrams show close agreement between observed and simulated runoff and sediment yield as most of the points are close to the 1:1 line indicating reasonable accurate simulation by the model (Figures 6 and 7).

The total simulated runoff and sediment yield during the calibration period were $131.2 \mathrm{~mm}$ and $9.0 \mathrm{Mg} \mathrm{ha}^{-1}$ against the observed values of $143.6 \mathrm{~mm}$ and $7.93 \mathrm{Mg} \mathrm{ha}^{-1}$, respectively. The deviation of the simulated runoff and sediment yield from the observed values was highest in high rainfall event of 22 September, in which the model slightly underpredicted the runoff but overpredicted the sediment yield. The model performance statistics during its calibration are given in Tables 5 and 6 . The model simulated runoff and sediment yield with reasonable accuracy as is reflected from low values of percent error (4.92 and 12.71), RMSE (0.44 mm and $\left.0.36 \mathrm{Mg} \mathrm{ha}^{-1}\right)$ and high values of correlation coefficient (0.94 and 0.97) and Nash-Sutcliffe model efficiency (88.0\% and $87.3 \%)$.

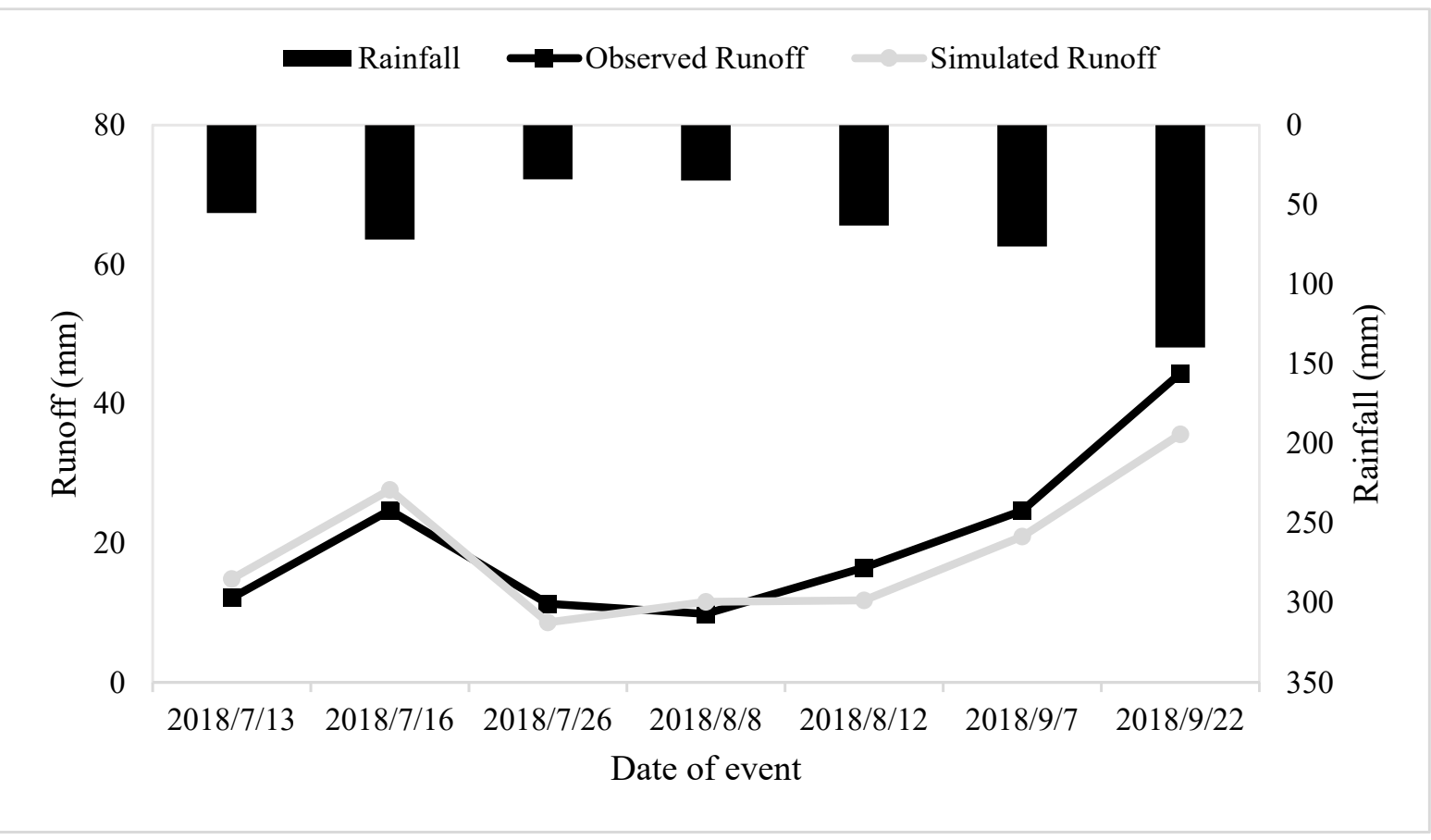

Figure 4. Observed and simulated storm-wise runoff during model calibration. 


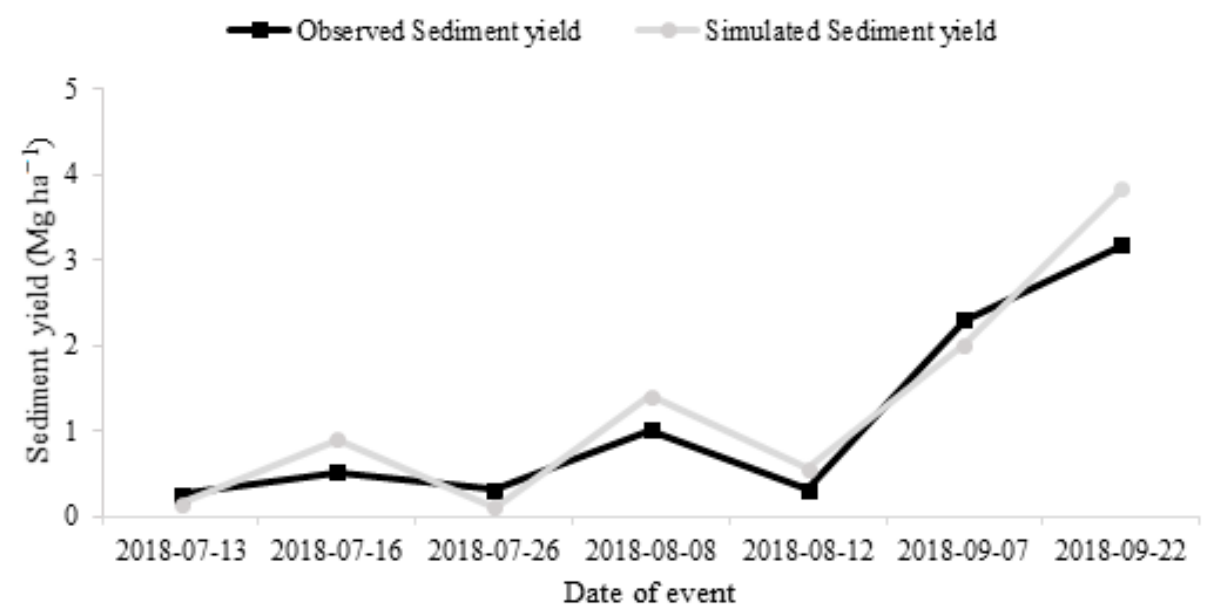

Figure 5. Observed and simulated storm-wise sediment yield during model calibration.

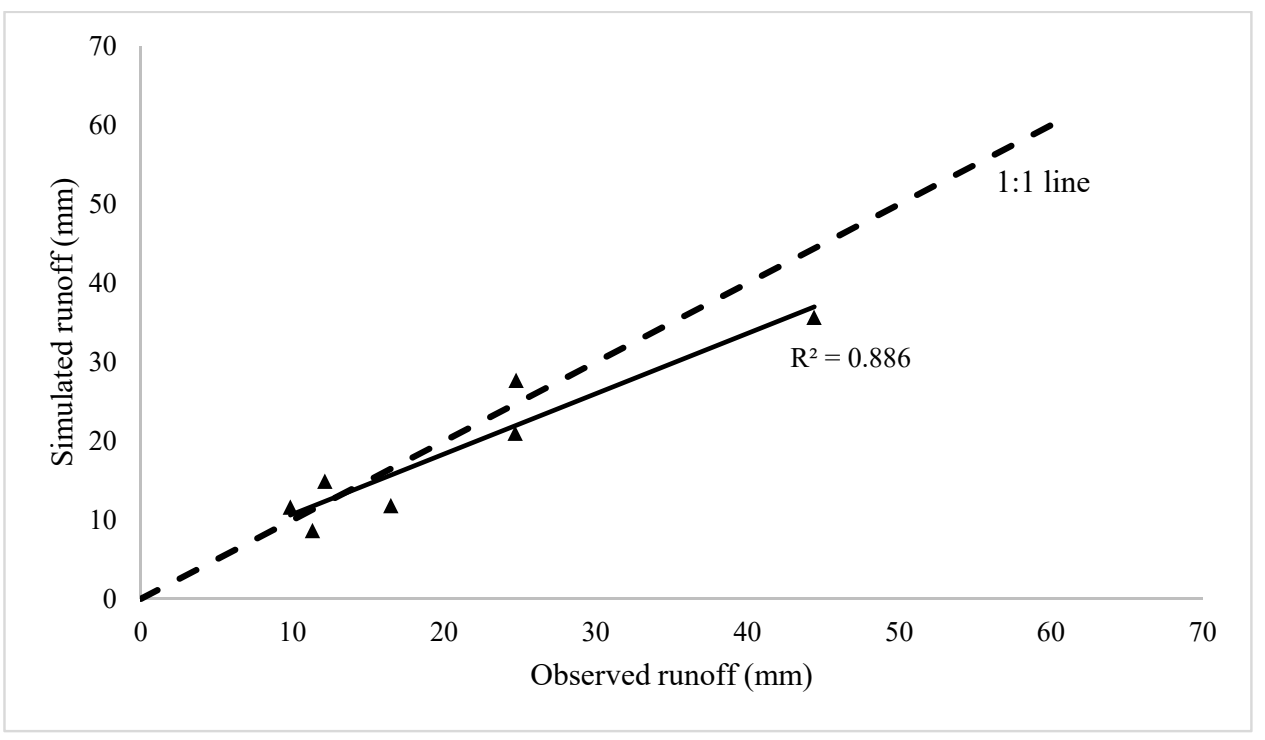

Figure 6. Comparison between observed and simulated storm-wise runoff during model calibration.

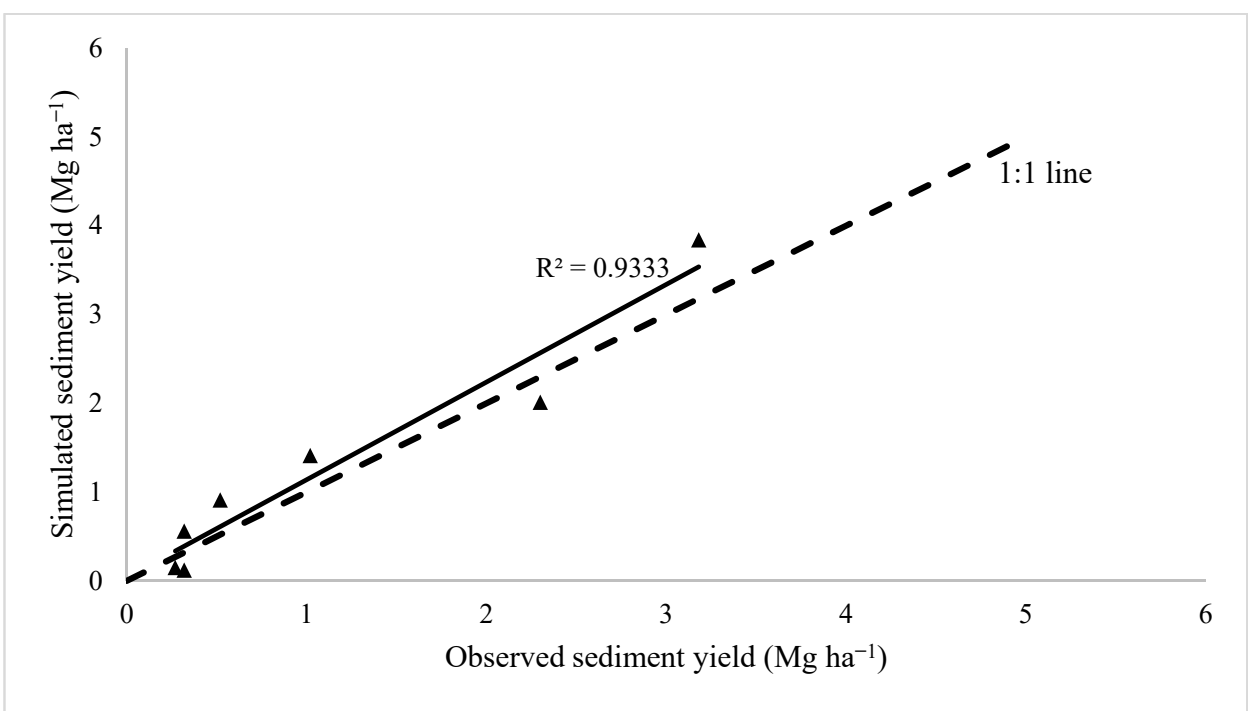

Figure 7. Comparison between observed and simulated storm-wise sediment yield during model calibration. 
Table 5. Test statistics for runoff simulation by the EROSION-3D model during the calibration period at micro-watershed $\mathrm{A}$.

\begin{tabular}{|c|c|c|}
\hline Statistical Parameters & Observed Runoff (mm) & Simulated Runoff (mm) \\
\hline Total & 143.57 & 131.21 \\
\hline Maximum & 44.38 & 35.65 \\
\hline RMSE (mm) & \multicolumn{2}{|c|}{0.44} \\
\hline Mean Percent error & \multicolumn{2}{|c|}{4.92} \\
\hline Correlation Coefficient & \multicolumn{2}{|c|}{0.94} \\
\hline Model efficiency (\%) & \multicolumn{2}{|c|}{88.0} \\
\hline
\end{tabular}

Table 6. Test statistics for sediment yield simulation by the EROSION-3D model during the calibration period at micro-watershed A.

\begin{tabular}{|c|c|c|}
\hline Statistical Parameters & $\begin{array}{l}\text { Observed Sediment Yield } \\
\qquad\left(\mathrm{Mg} \mathrm{ha}^{-1}\right)\end{array}$ & $\begin{array}{l}\text { Simulated Sediment Yield } \\
\qquad\left(\mathrm{Mg} \mathrm{ha}^{-1}\right)\end{array}$ \\
\hline Total & 7.93 & 9.0 \\
\hline Maximum & 3.18 & 3.84 \\
\hline $\operatorname{RMSE}\left(\mathrm{Mg} \mathrm{ha}^{-1}\right)$ & \multicolumn{2}{|c|}{0.365} \\
\hline Percent Error & \multicolumn{2}{|c|}{12.71} \\
\hline Correlation Coefficient & \multicolumn{2}{|c|}{0.97} \\
\hline Model Efficiency (\%) & \multicolumn{2}{|c|}{88.32} \\
\hline
\end{tabular}

\subsection{Model Validation}

After calibration, validation is an important step in which performance of the calibrated model is judged using a different dataset. In the present study, the model which was calibrated using data from micro-watershed A, was validated using 11 rainstorm data observed at micro-watershed $\mathrm{B}$. The results of validation are given below:

The storm-wise observed and simulated runoff and sediment yield along with the corresponding rainfall during the model validation period are given in Figures 8 and 9. The observed and simulated values of runoff and sediment yield are in close agreement indicating good simulation by the model. The scatter plot diagrams show observed and simulated values are close to the 1:1 line (Figures 10 and 11).

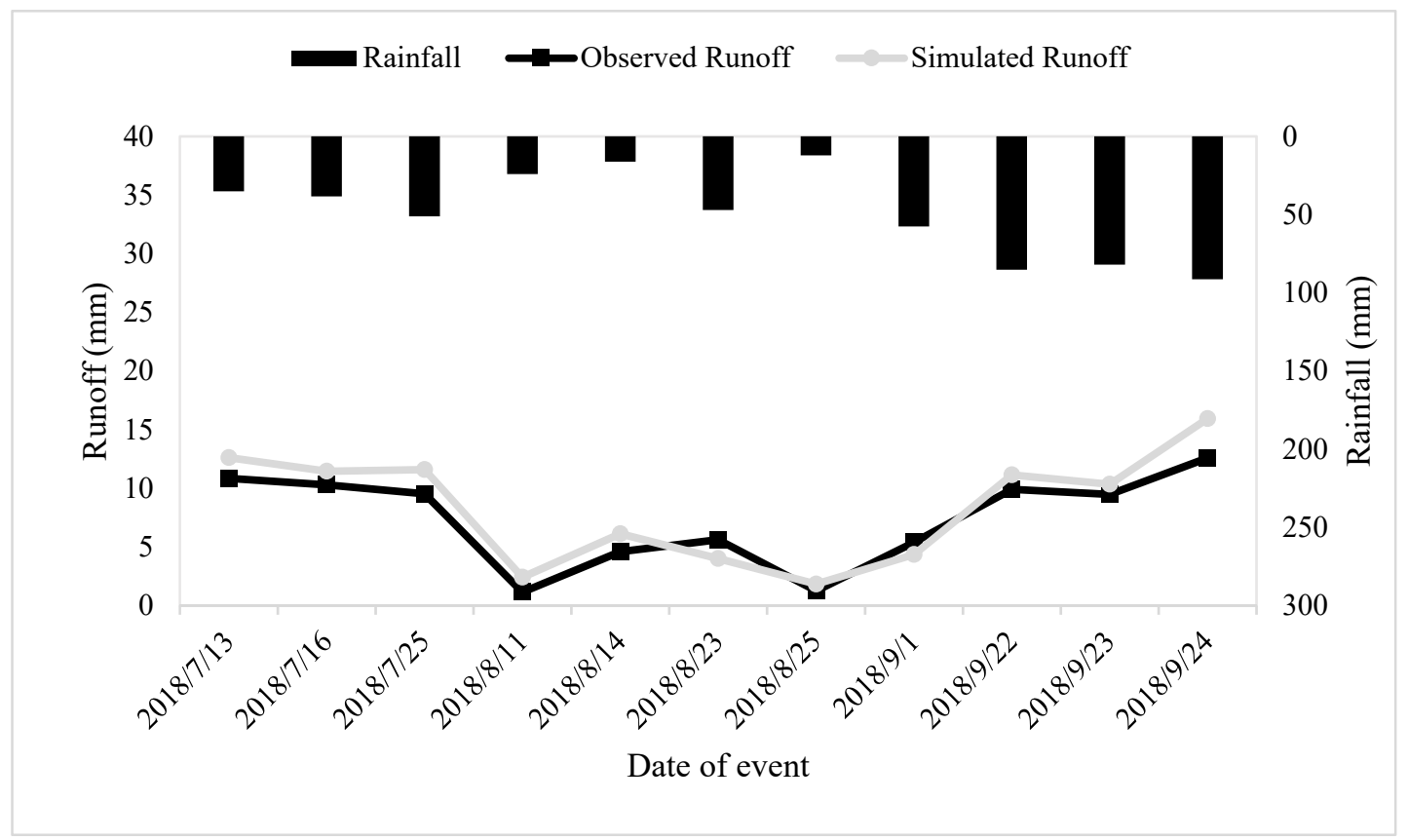

Figure 8. Observed and simulated storm-wise runoff during model validation. 


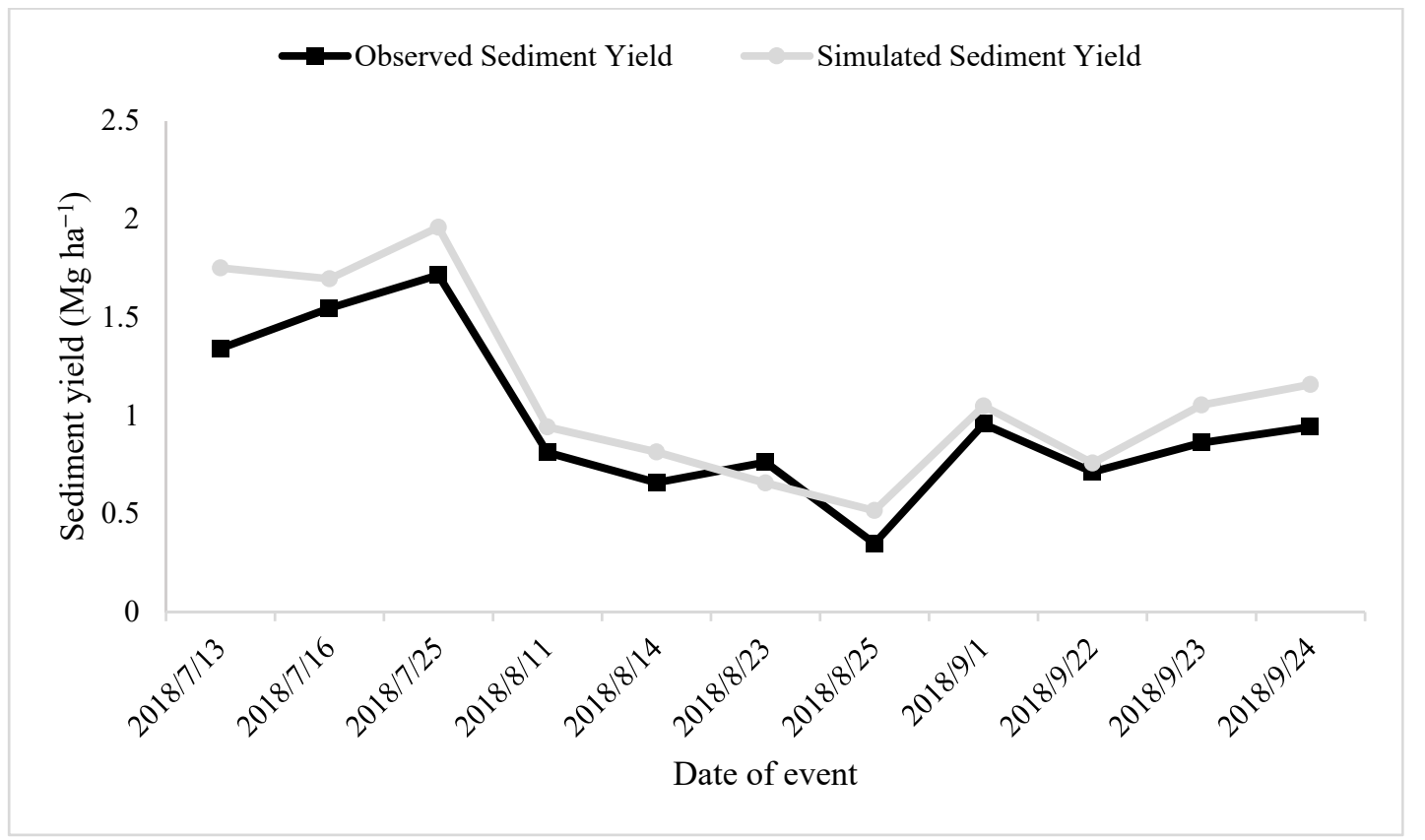

Figure 9. Observed and simulated storm-wise sediment yield during model validation.

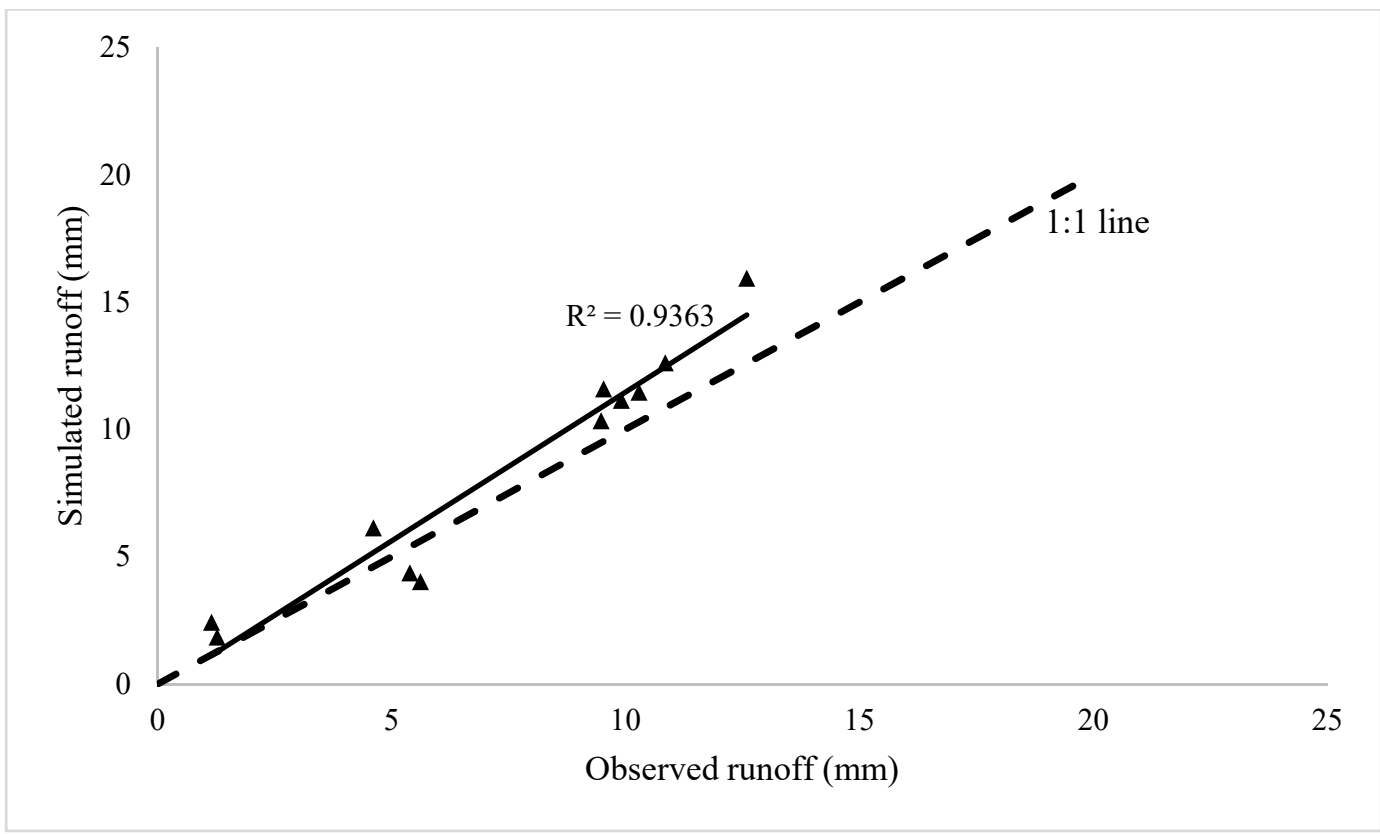

Figure 10. Comparison between observed and simulated storm-wise runoff during model validation.

The total simulated runoff $(91.85 \mathrm{~mm})$ and sediment yield $\left(12.35 \mathrm{Mg} \mathrm{ha}^{-1}\right)$ during the validation period were higher than the observed runoff $(80.69 \mathrm{~mm})$ and sediment yield (10.66 $\left.\mathrm{Mg} \mathrm{ha}^{-1}\right)$. The lower values of percent error (21.63 and 17.16) and RMSE (1.65 mm and $\left.0.19 \mathrm{Mg} \mathrm{ha}^{-1}\right)$ and higher values of correlation coefficient (0.96 and 0.97) and NashSutcliffe model efficiency ( $82.8 \%$ and $74.5 \%$ ) indicate the reasonably accurate simulation of runoff and sediment yield by the EROSION-3D model (Tables 7 and 8). 


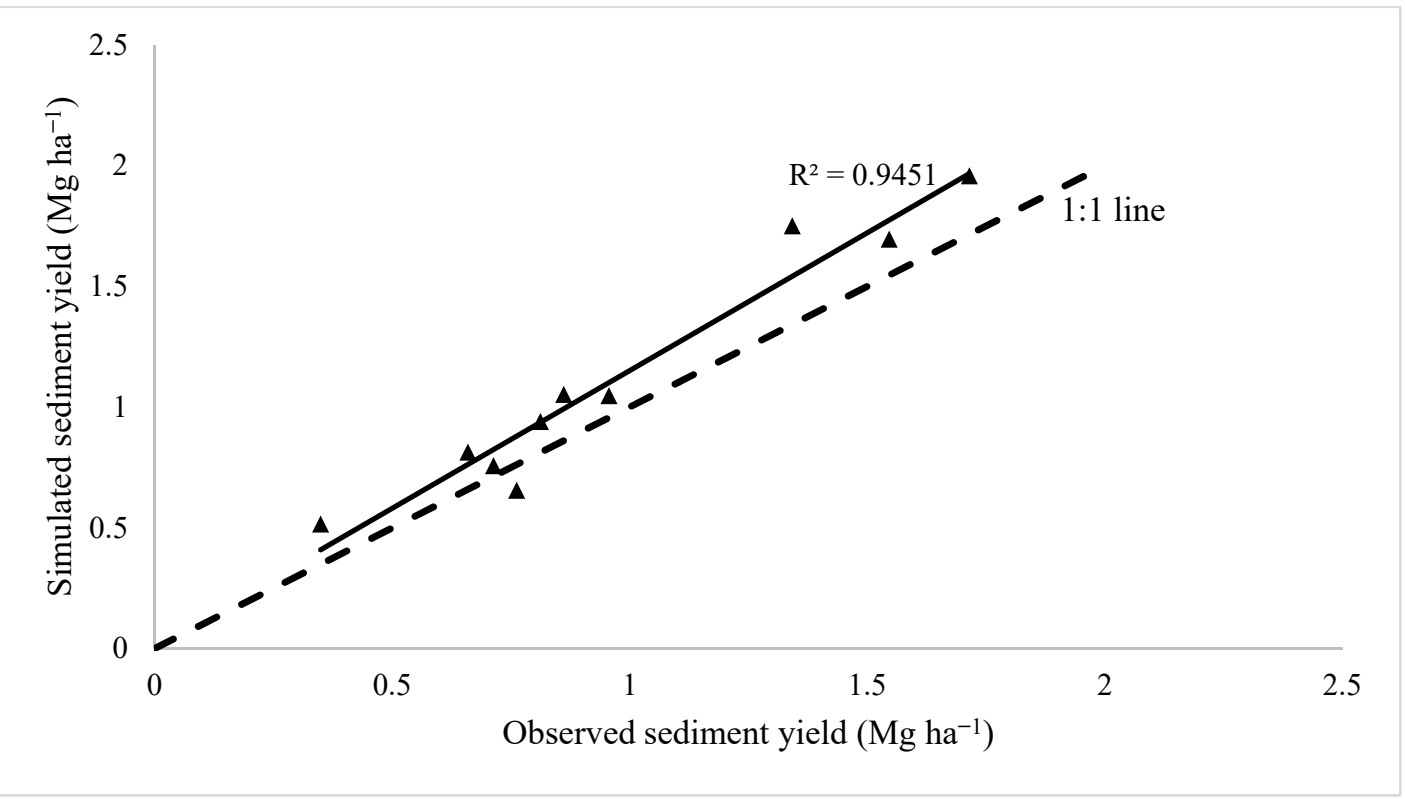

Figure 11. Comparison between observed and simulated storm-wise sediment yield during model validation.

Table 7. Test statistics for runoff simulation by the EROSION-3D model during the validation period at micro-watershed B.

\begin{tabular}{|c|c|c|}
\hline Statistical Parameters & Observed Runoff (mm) & Simulated Runoff (mm) \\
\hline Total & 80.69 & 91.85 \\
\hline Maximum & 12.59 & 15.94 \\
\hline RMSE (mm) & \multicolumn{2}{|c|}{1.65} \\
\hline Percent Error & \multicolumn{2}{|c|}{21.63} \\
\hline Correlation Coefficient & \multicolumn{2}{|c|}{0.96} \\
\hline Model efficiency (\%) & \multicolumn{2}{|c|}{82.77} \\
\hline
\end{tabular}

Table 8. Test statistics for sediment yield simulation by the EROSION-3D model during the validation period at micro-watershed B.

\begin{tabular}{|c|c|c|}
\hline Statistical Parameters & $\begin{array}{l}\text { Observed Sediment Yield } \\
\left(\mathrm{Mg} \mathrm{ha}^{-1}\right)\end{array}$ & $\begin{array}{l}\text { Simulated Sediment Yield } \\
\left(\mathrm{Mg} \mathrm{ha}^{-1}\right)\end{array}$ \\
\hline Total & 10.66 & 12.35 \\
\hline Maximum & 1.72 & 1.96 \\
\hline $\operatorname{RMSE}\left(\mathrm{Mg} \mathrm{ha}^{-1}\right)$ & \multicolumn{2}{|c|}{0.19} \\
\hline Percent Error & \multicolumn{2}{|c|}{17.16} \\
\hline Correlation Coefficient & \multicolumn{2}{|c|}{0.97} \\
\hline Model Efficiency (\%) & \multicolumn{2}{|c|}{74.48} \\
\hline
\end{tabular}

\section{Discussion}

It was noted that the model overestimated the higher values of soil erosion. It might be because of the fact that the model failed to take into account the contribution made by the erosion control practices while estimating the same. Furthermore, the efficiency of the model also decreased subsequently as the magnitude of soil loss increases. Nemetova et al. [40] also reported the same problem of overestimation of the soil erosion rate when the magnitude of the sediment yield was higher.

The soil erosion map (Figure 12) shows the spatial distribution of soil erosion in the study watershed. It can be seen that maximum soil erosion was recorded from that part of the watershed which was under maize cultivation. Maize being a widely spaced and thus erosion permitting crop caused a high amount of soil erosion from the watershed. Maize is 
usually grown on ridges in the Shivalik foothills at the spacing of $60 \mathrm{~cm}$. The inter-row space between the maize rows in sloping fields may act as channel through which runoff can flow easily resulting in higher soil erosion. The calibrated values of surface roughness and resistance to erosion for maize is relatively less than the corresponding values for moong and mash which shows that the soils under maize cultivation are more susceptible to soil erosion. At the commencement of the monsoon season, the area under moong and mash cultivation was found to be erosion prone. However, in the later stages, mash and moong proved to be beneficial in controlling soil erosion which may be attributed to the fact that the mash and moong quickly establish a good canopy cover which dissipates the rainfall impact thereby resulting in lower runoff and soil erosion [41]. Nemetova \& Kohnova [42] also observed the maximum soil loss from scenario of fallow land. Gao et al. [43] also reported that the runoff and soil loss were more in maize cultivation as compared to the soyabean crop. Therefore, the agricultural practices and land cover conditions play an important role in describing the soil erosion process. Hence, these factors must be properly taken into account while studying the soil erosion process [44].

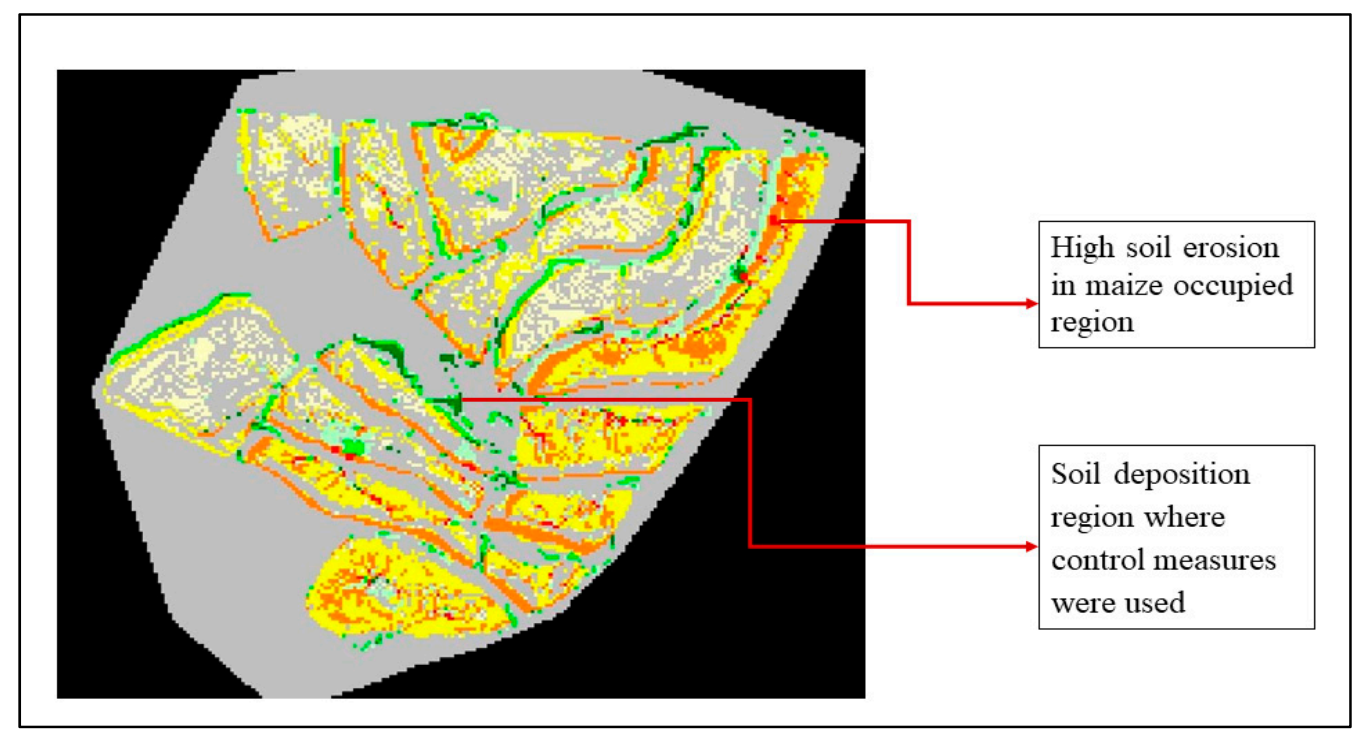

Figure 12. Soil erosion map by the EROSION-3D model.

The study also revealed that the presence of permanent grasses in the watershed as zone of deposition. Furthermore, the region where soil erosion control practices such as contour bunding or conservation tillage were practiced, seemed to be helpful in controlling soil erosion. Similar observations regarding the effect of land use on rate of soil erosion were made by Nemetova et al. [40]. As the area under perennial grasses proved to be helpful in controlling erosion rates and found to be a deposition zone, an increase in the area under its cultivation will be a good measure to check soil erosion. Similar recommendations were also made by Routschek et al. [33]. Dass et al. [45] and Singh et al. [46] also reported that perennial grasses when grown as vegetative barriers reduce the runoff and soil erosion and increase the crop productivity. The comparison between contribution of perennial grasses and agronomic measures for erosion control shows that the former proved to be much more effective in soil erosion control as compared to the latter. Although, a combination of both may be the best management practice to curb the threat of soil erosion. Schob et al. [29] tested different erosion control measures and recommended the combination of pasture and agronomic measures as the most appropriate method for effective erosion control. Yousuf et al. [47] simulated the impact of erosion control structures (sedimentation basins and check dams) and reported that runoff and sediment yield decreased by $72 \%$ and $90 \%$ due to the implementation of these structures. Yaekob et al. [48] also reported that soil and water conservation structures reduced the sediment yield by about $74 \%$. 
Although model predictions regarding runoff estimation were very much acceptable, yet, one important trend was observed in the runoff estimation. It was the model's inability to simulate runoff for high magnitude rainstorms precisely which may be due to the surface sealing phenomenon wherein soil particles clog the soil pores decreasing the infiltration rate. This process may not be well accounted by the model while simulating the runoff. In the EROSION-3D model, the surface sealing phenomenon is represented by the skin factor, hence this parameter needs to calibrated more precisely. Another reason could be that during high-magnitude storms, the runoff may follow different pathways to the streams so that the watershed behaves differently. During the validation period, the model slightly overestimated the sediment yield values of high magnitude. It might be because of the model's inability to take into account the role of tillage practices while simulating the erosion rate. Keeping in view the complex nature and heterogeneity of the rainfall-runofferosion process, the performance of the EROSION-3D model has been satisfactory for simulation of runoff and sediment yield from watersheds located in the Shivalik foot-hills of Northwest India.

\section{Conclusions}

Quantification of runoff and sediment yield is pre-requisite for implementation of conservation measures at the watershed scale. The present study was undertaken to evaluate the performance of the EROSION-3D model to simulate runoff and sediment yield from micro-watersheds located in the Shivalik region of Northwest India. The model was calibrated by adjusting the three soil-related parameters, skin factor, resistance to erosion and surface roughness. The results of the study indicate that the simulation accuracy of the EROSION-3D model is reasonably good for simulation of runoff and sediment yield. However, the model efficiency for runoff was better than sediment yield which could be due to the more complex and heterogeneous nature of the erosion process than the runoff generation process. The wide-row crops such as maize resulted in higher soil erosion as compared to the crops having less row-to-row spacing and high foliage such as moong and mash. The inclusion of perennial grasses in a watershed proved beneficial, however, sole perennial grasses may not be economically suitable, so a combination of perennial grasses with cash crops may be adopted better. Therefore, the EROSION-3D may act as base for selection of suitable crops and management practices for the policy makers. Hence, the EROSION-3D model is a very effective tool for quantifying runoff and sediment yield in the Shivalik region of India and may serve as a decision support tool for soil and water management decisions owing of its low input data requirements and reasonable accuracy.

Author Contributions: Conceptualization, M.S. and K.H.; methodology, M.v.W. and A.Y.; software, H.S., S.S., M.v.W. and A.Y.; validation, A.Y. and M.v.W.; formal analysis, S.S. and H.S.; investigation, M.v.W. and A.Y.; resources, A.H.A., K.H., A.Y.E., H.R.A., E.E.H. and M.S.; data curation, M.v.W.; writing, A.Y. and H.S.; writing-review and editing, A.Y., A.Y.E., H.R.A., A.H.A. and E.E.H.; visualization, M.S. and A.Y.; supervision, M.S. and K.H.; project administration, M.S.; A.Y.E., H.R.A., E.E.H., A.H.A. and K.H.; funding acquisition, A.H.A., K.H., A.Y.E, H.R.A. and E.E.H. All authors have read and agreed to the published version of the manuscript.

Funding: This research was funded by IPROconsult, Germany, (grant number 2018/52) and Taif University Researchers Supporting Project grant number (TURSP-2020/252), Taif University, Taif, Saudi Arabia.

Institutional Review Board Statement: Not applicable.

Informed Consent Statement: Not applicable.

Data Availability Statement: All data are available in the manuscript.

Acknowledgments: The authors thank Taif University Researches Supporting Project number (TURSP-2020/252), Taif University, Taif, Saudi Arabia for supporting this study.

Conflicts of Interest: The authors declare no conflict of interest. 


\section{References}

1. Ganasri, B.P.; Ramesh, H. Assessment of soil erosion by RUSLE model using remote sensing and GIS-A case study of Nethravathi Basin. Geosci. Front. 2016, 7, 953-961. [CrossRef]

2. Sivakumar, M.V.K. Interactions between climate and desertification. Agric. For. Meteorol. 2007, 142, 143-155. [CrossRef]

3. Mythili, G.; Goedecke, J. Economics of land degradation in India. In Economics of Land Degradation and Improvement-A Global Assessment for Sustainable Development; Nkonya, E., Mirzabaev, A., von Braun, J., Eds.; Springer: Cham, Switzerland, 2016; pp. 431-470.

4. FAO; ITPS. The Status of the World's Soil Resources (Main Report); Food and Agriculture Organization of the United Nations: Rome, Italy, 2015.

5. Mohammed, A.; Alsfadi, K.; Talukdar, S.; Kiwan, S.; Hennawi, S.; Alshihabi, O.; Sharaf, M.; Harsanyie, S. Estimation of soil erosion risk in southern part of Syria by using RUSLE integrating geo informatics approach. Remote Sens. Appl. Soc. Environ. 2020, 20, 100375. [CrossRef]

6. Gomiero, T. Soil Degradation, Land Scarcity and Food Security: Reviewing a Complex Challenge. Sustainability. $2016,8,281$. [CrossRef]

7. Dutta, S. Soil erosion, sediment yield and sedimentation of reservoir: A review. Model. Earth System Environ. 2016, 2, 123. [CrossRef]

8. Ezz-Aldeen, M. Sedimentation and Its Challenges for the Sustainability of Hydraulic Structures. A Case Study of the Mosul Dam Pumping Station. Ph.D. Thesis, Lulea University of Technologies, Luleå, Sweden, 2020.

9. Young, R.; Orsini, O.; Fitzpatrick, I. Soil degradation: A major threat to humanity. Sustain. Food Trust. A Glob. Voice Sustain. Food Health 2015, 38, 1-15

10. Bhattacharyya, R.; Ghosh, B.N.; Mishra, P.K.; Mandal, B.; Rao, C.S.; Sarkar, D.; Das, K.; Anil, K.S.; Lalitha, M.; Hati, K.M.; et al Soil degradation in India: Challenges and potential solutions. Sustainability 2015, 7, 3528-3570. [CrossRef]

11. Pal, S. Identification of soil erosion vulnerable areas in Chandrabhaga river basin: A multi-criteria decision approach. Model. Earth Syst. Environ. 2016, 2, 1-11. [CrossRef]

12. ICAR. Degraded and Wastelands of India: Status and Spatial Distribution; Krishi Anusandhan Bhavan I, Pusa: New Delhi, India, 2010.

13. Shardam, V.N.; Ojasvi, P.R. A revised soil erosion budget for India: Role of reservoir sedimentation and land-use protection measures. Earth Surf. Process. Landf. 2016, 41, 2007-2023. [CrossRef]

14. Lal, R. Restoring soil quality to mitigate soil degradation. Sustainability 2015, 7, 5875-5895. [CrossRef]

15. Singh, M.J.; Khera, K.L. Nomographic estimation and evaluation of soil erodibility under simulated and natural rainfall conditions. Land Degrad. Develop. 2009, 20, 471-480. [CrossRef]

16. Puja, J. N.; Chadha, J. Biodiversity in the Shivalik Ecosystem of Punjab, India; PSCST-Chandigarh: Chandigarh, India, $2006 ;$ pp. 1-19.

17. Kukal, S.S.; Singh, M.J. Soil erosion and conservation. In Soil Science-An Introduction; Indian Society of Soil Conservation: New Delhi, India, 2015; pp. 217-254.

18. Yousuf, A.; Bhardwaj, A.; Tiwari, A.K.; Bhatt, V.K. Simulation of runoff and sediment yield from a small forest watershed in Shivalik foot-hills using WEPP model. Indian J. Soil Conserv. 2017, 45, 21-27.

19. Bhardwaj, A.; Kaushal, M.P. Two- dimensional physically based finite element runoff model for small agricultural watershed: I. Model development. Hydrol. Process. 2011, 23, 397-407. [CrossRef]

20. Revilla-Romero, B.; Beck, H.E.; Burek, P.; Salamon, P.; De-Roo, A.; Thielen, J. Filling the gaps: Calibrating a rainfall-runoff model using satellite-derived surface water extent. Remote Sens. Environ. 2015, 171, 118-131. [CrossRef]

21. Yousuf, A.; Bhardwaj, A. Development and application of travel time based gridded runoff and sediment yield model. Int. J. Environ. Sci. Technol. 2021, 19, 1-16. [CrossRef]

22. Zhang, B.; Govindaraju, R.S. Geomorphology-based artificial neural networks GANNs for estimation of direct runoff over watersheds. J. Hydrol. 2003, 273, 18-34. [CrossRef]

23. Bharti, B.; Pandey, A.; Tripathi, S.K.; Kumar, D. Modelling of runoff and sediment yield using ANN, LS-SVR, REPTree and M5 models. Hydrol. Res. 2017, 48, 1489-1507. [CrossRef]

24. Kim, S.; Kisi, O.; Seo, Y.; Singh, V.P.; Lee, C.J. Assessment of rainfall aggregation and disaggregation using data-driven models and wavelet decomposition. Hydrol. Res. 2016, 48, 99-116. [CrossRef]

25. Sharma, N.; Zakaullah, M.; Tiwari, H.; Kumar, D. Runoff and sediment yield modeling using ANN and support vector machines: A case study from Nepal watershed. Model. Earth Syst. Environ. 2015, 1, 23. [CrossRef]

26. Kushwaha, N.L.; Yousuf, A. Soil erosion risk mapping of watersheds using RUSLE, remote sensing and GIS: A review. Res. J. Agric. Sci. 2017, 8, 269-277.

27. Werner, M.V. 2010 Data Base-Processor User Manual; Geognostic Software: Berlin, Germany, 2020.

28. Schmidt, J.; Werner, M.V.; Michael, A. Application of the EROSION-3D model to the CATSOP watershed, The Netherlands. Catena 1999, 37, 449-456. [CrossRef]

29. Schob, A.; Schmidt, J.; Tenholtern, R. Derivation of site-related measures to minimise soil erosion on the watershed scale in the Saxonian loess belt using the model EROSION-3D. Catena 2006, 68, 153-160. [CrossRef]

30. Schindewolf, M.; Bornkampf, C.; Werner, M.; Schmidt, J. Simulation of reservoir siltation with a process-based soil loss and deposition model. Earth Planet. Sci. 2015, 10, 41-57. 
31. Honek, D.; Nemetova, Z.; Latkova, T. Application of physically-based EROSION-3D model for small catchment. In Proceedings of the 17th International Multidisciplinary Scientific Geo Conference SGEM, Vienna, Austria, 23 November 2017.

32. Kaur, N.; Yousuf, A.; Singh, M.J. Long term rainfall variability and trend analysis in lower Shivaliks of Punjab, India. Mausam 2021, 72, 571-582. [CrossRef]

33. Routschek, A.; Schmidt, J.; Kreienkemp, F. Impact of climate change on soil erosion-A high-resolution projection on catchment scale until 2100 in Saxony/Germany. Catena 2014, 121, 99-109. [CrossRef]

34. Schindewolf, M.; Schmidt, J. Parameterization of the EROSION 2D/3D soil erosion model using a small-scale rainfall simulator and upstream runoff simulation. Catena 2012, 91, 47-55. [CrossRef]

35. Nemetova, Z.; Honek, D.; Kohnova, S.; Hlavkova, K.; Michalkova, M.S.; Socuvka, V.; Vliskova, Y. Validation of the EROSION-3D model through measured bathymetric sediments. Water 2020, 12, 1082. [CrossRef]

36. Schoeneberger, P.J.; Wysocki, D.A.; Benham, E.C.; Soil Survey Staff. Field Book for Describing and Sampling Soils, Version 3.0; Natural Resources Conservation Service, National Soil Survey Center: Lincoln, NE, USA, 2012.

37. Lenz, J.; Yousuf, A.; Schindewolf, M.; Werner, M.; Hartsch, K.; Singh, M.J.; Schmidt, J. Parameterization for EROSION-3D Model under simulated rainfall conditions in lower Shivaliks of India. Geosciences 2018, 8, 396. [CrossRef]

38. Sorooshian, S.; Gupta, V.K. Model calibration. In Computer Models of Watershed Hydrology; Singh, V.P., Ed.; Water Resources Publications: Highlands Ranch, CO, USA, 1995; pp. 23-68.

39. Nash, J.E.; Sutcliffe, J.V. River flow forecasting through conceptual models. Part 1: A discussion of principles. J. Hydrol. 1970, 10, 282-290. [CrossRef]

40. Nemetova, Z.; Kohnova, S.; Flodes, G. Evaluation of effect of different crop types on soil water erosion: Case study of the Myjava Hill Land, Slovakia. IOP Conf. Ser. Mater. Sci. Eng. 2019, 603, 022026. [CrossRef]

41. Khokhar, A.; Yousuf, A.; Singh, M.J.; Sharma VSingh, P.S.; Gajjala, R.C. Impact of land configuration and strip-intercropping on runoff, soil loss and crop yields under rainfed conditions in the Shivalik foothills of north-west, India. Sustainability 2021, 13, 6282. [CrossRef]

42. Nemetova, Z.; Kohnova, S. Comparison of sediment loss modelling by using the physically-based EROSION-3D model and the USPED empirical model: A case study of the Svacenicky Creek catchment (Slovakia). IOP Conf. Ser. Mater. Sci. Eng. 2019, 471, 022082. [CrossRef]

43. Gao, J.; Bai, Y.; Cui, H.; Zhang, Y. The effect of different crops and slopes on runoff and soil erosion. Water Pract. Technol. 2020, 15, 773-780. [CrossRef]

44. Geleta, I.H. Watershed Sediment Yield Modeling in Data Scarce Areas. Ph.D. Thesis, University of Stuttgart, Stuttgart, Germany, 2011.

45. Dass, A.; Sudhishri, S.; Lenka, N.K.; Patnail, U.S. Runoff capture through vegetative barriers and planting methodologies to reduce erosion, and improve soil moisture, fertility and crop productivity in southern Orissa, India. Nutr. Cycl. Agroecosyst. 2011, 89, 45-57. [CrossRef]

46. Singh, M.J.; Yousuf, A.; Sharma, S.C.; Bawa, S.S.; Khokhar, A.; Sharma, V.; Kumar, V.; Singh, S.; Singh, S. Evaluation of vegetative barriers for runoff, soil loss and crop productivity in Kandi region of Punjab. J. Soil Water Conserv. 2017, 16, 325-332. [CrossRef]

47. Yousuf, A.; Bhardwaj, A.; Prasad, V. Simulating the impact of conservation interventions on runoff and sediment yield in a degraded watershed using the WEPP model. Ecopersia 2021, 9, 191-205.

48. Yaekob, T.; Tamene, L.; Gebrehiwot, S.G.; Demissie, S.S.; Adimassu, Z.; Woldearegay, K.; Mekonnen, K.; Amede, T.; Abera, W.; Recha, J.W.; et al. Assessing the impacts of different land uses and soil and water conservation interventions on runoff and sediment yield at different scales in the central highlands of Ethiopia. Renew. Agric. Food Syst. 2020, 35, 1-15. [CrossRef] 